\title{
28 Research Square \\ Development of A Methodology For Predicting Landslide Hazards At A Regional Scale
}

\section{Blanche Richer}

Université du Québec à Chicoutimi

Ali Saeidi ( $\boldsymbol{D}$ ali_saeidi@uqac.ca )

Université du Québec à Chicoutimi https://orcid.org/0000-0001-6954-5453

Maxime Boivin

Université du Québec à Chicoutimi

\author{
Alain Rouleau \\ Université du Québec à Chicoutimi
}

\section{Research}

Keywords: Sensitive clay, landslide, risk analysis, zonation mapping, electrical induction, TEM, back analysis, 3D modeling

Posted Date: November 1st, 2021

DOI: https://doi.org/10.21203/rs.3.rs-1000469/v1

License: (c) (1) This work is licensed under a Creative Commons Attribution 4.0 International License. Read Full License 


\section{Abstract}

Landslide risk analysis is a common geotechnical evaluation and aims to protect life and infrastructure. In the case of sensitive clay zones, landslides can affect large areas and are difficult to predict. Here we propose a methodology to determine the landslide hazard across a large territory, and we apply our approach to the Saint-Jean-Vianney area, Quebec, Canada. The initial step consists of creating a 3D model of the surficial deposits of the target area. After creating a chart of the material electrical resistivity adapted for eastern Canada, we applied electric induction to interpret the regional soil. We collected samples from the main lithologies and estimated selected soil geotechnical parameters in laboratory tests. We transposed parameter values obtained from the samples to a larger scale that of a slope using the results of a back analysis undertaken on an earlier, smaller slide within the same area. The regional $3 \mathrm{D}$ model of deposits is then used to develop a zonation map of at-risk slopes and their respective constraint areas with the study region. This approach allowed us to target specific areas where a more precise stability analysis would be required. Our methodology offers an effective tool for stability analysis in territories characterized by the presence of sensitive clays.

\section{Introduction}

Landslides affect numerous areas across the globe, damage infrastructure, and cause the loss of human life. This phenomenon occurs in various soils, including sands and clays. When they occur in clay soils, and depending on the sensitivity of the clay layers, landslides can become unpredictable and affect large areas. Hazard assessments thus represent vital tools in identifying and minimizing landslide risk. These assessments are based on the stratigraphy and the geometry of the different soil layers, soil types, and the assessment of geotechnical parameters, such as the shear strength of the soils (L'Heureux et al. 2014).

An initial series of key factors of landslide risk analysis involves slope geometry and terrain stratigraphy, which combine several elements that control landslide behavior. These elements include various aspects of ground topography, such as the inclination and the orientation of the slope surface and bedding planes, the presence and depth of incision by surface streams, and the proximity of the bedrock (Geertsema and L'Heureux 2014). Combining a sufficiently precise topography with a reliable description of the different soil layers permits creating an accurate 3D model of the zone in question. The accuracy of this 3D geological model is critical for an appropriate assessment of landslide and other geotechnical risks at a regional scale. Topographic information is obtained from existing maps, from geostatistical interpolation based on site surveys, and from LiDAR (light detection and ranging) surveys. Stratigraphic data is acquired through intrusive methods, such as drilling, or non-intrusive methods, such as geophysical surveys. Drilling provides core samples, which are used to identify the nature of the different soil units and serve for further analyses. Surface geophysical methods identify the stratigraphy; these methods include seismic refraction, electrical resistivity tomography (ERT), and transient electromagnetic (TEM) methods (Mussett and Khan 2000). 
Of these abovementioned methods, core sampling is the most accurate but also the most expensive. Given that the required 3D model must often cover a large territory, a more suitable approach involves a large quantity of quick and inexpensive surveys across the area. When choosing the investigation methods, it is important to select those best suited to the specific area under study. In the case of a zone characterized by a great thickness of sensitive clay, a powerful detonation-required for seismic refraction -could trigger a slide and is therefore not appropriate. Electrical resistivity can differentiate clay from sand, gravel, and bedrock; this approach is useful in areas where sensitive clay layers must be differentiated from other geological units (Mussett and Khan 2000). This technique also has an advantage of being able to detect variations in porewater salinity of the water, which affects the structure of clay. Finally, TEM is often favored because of its practicality. It is easy to transport, its installation is fast, the duration of the survey is relatively short and it can be used in all kinds of conditions. Nonetheless, interpreting these geophysical surveys can be difficult and requires adapting the interpretations to the specific target area.

A second series of key factors of landslide hazard assessment includes landslide type and the potential extent of the slide. Landslide type depends on the soil type. Multiple sophisticated methods have been developed to evaluate the possibility of landslides in clayed soils and other granular materials. These approaches include analytical and numerical stability analyses using SRF (strength reduction factor) for estimating a single, commonly spherical, failure surface landslide (Richer et al. 2020).

Extensive areas in eastern Canada are covered by sensitive clays. These clays are fine-grained plastic and cohesive soils that may or may not contain clay minerals (Holtz and Kovacs 1981). Sensitivity is an important parameter and is defined as the ratio of the undisturbed soil strength $\left(\mathrm{S}_{\mathrm{u}}\right)$ to the remolded shear strength $\left(\mathrm{S}_{\mathrm{r}}\right)$ (L'Heureux et al. 2014). The "sensitive" qualifier is assigned to a soil having a sensitivity $\left(S_{t}\right)$ greater than 1 . Sensitive clays were formed in a post-glaciation context. In North America, the retreat of the Laurentide ice sheet, which began between 18 and $13 \mathrm{ka}$ BP depending on the region (Dyke and Prest 1987), was followed by a marine invasion along much of the isostatically depressed coastline. The clay deposited on the coastal seafloor contained an important quantity of polyvalent cations that flocculated to form a relatively strong structure. Following the isostatically forced regression, the clay was exposed to leaching by fresh meteoric water. This leaching increased the interparticle repulsive forces.

According to the classification of Varnes (1978), and its modification by Hungr et al. (2014), sensitive clays can produce a progressive spread or a flow landslide, also called a flowslide. Both categories of landslides are highly retrogressive (Mitchell and Klugman 1979; Marko et al. 2010; Demers et al. 2014).

Given the complexity of landslides in sensitive clays, determining the landslide constraint zones is commonly based on geometric criteria. The primary methods for zoning retrogression distance include the 1:15 method (Haugen, Tveit, and Heyerdahl 2017), the "natural hazards-infrastructure for floods and slides" method (Natural hazards-infrastructure for floods and slides 2016), and the Norwegian Geotechnical Institute (NGI) method (Haugen, Tveit, and Heyerdahl 2017; Turmel et al. 2018). These 
approaches establish the limit of the retrogression distance at $X$ times the height of the slope, with $X$ varying from 2 to 15 depending on the method and the soil properties. The distance is calculated from the toe of the slope or from the base of the critical failure surface. In Quebec, a commonly used method is based on a statistical analysis of previous retrogressive landslides in the same area (Turmel et al. 2018). All these methods produce conservative results but do not cover worst case scenarios, which are probabilistically quite rare.

The third series of key factors is the accurate estimation of geotechnical parameters in the laboratory and estimating these parameters at the actual in situ scale. The geotechnical parameters of the different soil layers produce large variations in behavior between a sample of collected material and that of an entire slope. A slope is commonly assumed to have a homogeneous composition; even in cases where a large number of samples are available, however, it is impossible to confirm the perfect homogeneity of a slope. Therefore, the scale effect has an important influence on the geotechnical parameters. One of the best approaches for determining the effective value of a soil parameter is through the back analysis of past landslides (Saeidi, Maazallahi, and Rouleau 2016). A back analysis can estimate the effective geotechnical parameters of the soil layer, where landslide scars are visible in the study area, and a reliable pre- and post-slide terrain geometry can be determined.

In this paper, we propose a methodology for predicting a regional-scale landslide occurrence and zoning a territory covered by sensitive clay slopes. This approach includes new developments in regard to two key aspects of predicting landslide occurrence: reliability of the 3D model and the assessment of geotechnical parameters. First, we obtain a reliable 3D geological model using geophysical methods and an adapted chart of the material electrical resistivity developed for a sensitive clay-covered territory. This chart is used to establish the stratigraphy of the territory and to create a 3D model of the soil deposits. We then obtain more precise values of the soil parameters through a back analysis of an earlier slide in the study area combined with laboratory data from soil samples collected from the study slide. The resulting geological model and geotechnical data are applied to the mapping of the at-risk area, and we use the method proposed by the Quebec (Canada) Ministry of Transport, the ministry responsible for evaluating terrain stability (MTMDET, 2017; Turmel et al., 2018). Slopes at risk can then be identified. We identify the different stages of a regional landslide risk analysis, describe a step-by-step procedure for this analysis, and highlight relationships between the various stages.

In the following sections, we present the selected applicable methods for acquiring data and provide a general methodology for assessing regional landslides. We then describe the specific study area to which we apply our approach and present and discuss the results and implications.

\section{Methods}

Figure 1 provides an overview of our methodology for determining a regional landslide risk. We detail the core procedures (blue rectangles in the figure) in the following sections. 


\subsection{Creating a database}

First, it is important to conduct an inventory of all relevant data available for the study area. This essential information includes regional soil types, their stratigraphy, and their physical, mechanical, and geotechnical characteristics. Borehole data, geotechnical surveys, and research reports are relevant data sources.

With the existing data in hand, it is easier to identify missing information. Geophysical methods, such as the transient electromagnetic (TEM) method proposed here, can be applied to fill these gaps. TEM is an easy-to-perform non-intrusive electromagnetic induction technique. Control points must be identified and are generally borehole logs, which provide a representative stratigraphy of the area. TEM surveys are first conducted near control points, and the results are used to calibrate survey results obtained elsewhere across the study area.

\subsection{Developing the 3D model}

Prior to undertaking the TEM surveys, we produce an initial regional stratigraphic model using the known data points. This stratigraphic model can then be used to calibrate the collected TEM data and thus obtain a more accurate estimate of the electrical resistivity of each layer.

Once the TEM surveys are completed, we compare the resistivity values obtained through the stratigraphy of control points selected from the known data points. The objective of this step is to associate a range of resistivity values to each layer described in the borehole logs. The Palacky chart (Palacky 1987) can also serve as a reference to identify aberrant values (Figure 2). This chart is adapted to the specific study region to identify soil types and is then used to interpret the stratigraphy recorded by all TEM surveys.

With all this data in hand, we can then overlay a grid over the study area to establish section lines. The number of created sections depends on the amount of data and the desired precision. For each section, the stratigraphies obtained from borehole logs and TEM surveys are displayed. Geological knowledge related to the deposition of each soil layer is applied to interpreting the stratigraphy between data points obtained from borehole logs and TEM surveys. At every point of intersection between two sections, both sections must display an identical interpretation of the stratigraphy. Once all sections are properly interpreted, the data set can be imported into 3D modeling software to create the 3D model.

\subsection{Assessing the values of soil geotechnical parameters}

Laboratory tests should be conducted on soil samples collected from each of the main soil types within the study area. The objective is to estimate the shear strength parameters (friction angle and cohesion) of each soil type and, for clays, the plasticity and liquidity indices. The obtained results serve as the basis for the back analysis described below.

The developed 3D model combined with site visits can identify the scars of past landslides within the study area. Pre-slide geometry is determined through the use of sequence aerial photography, LiDAR 
surveys, previous research, and the differential localization of known structures both pre- and post-slide (Saeidi, Maazallahi, and Rouleau 2016). These marker points are then entered into a conceptual model of the slide area. Analytical or numerical methods can then be used, and realistic values are assigned to all soil materials present on the slope. The aim is to create the original slide conditions and obtain a failure surface that is similar to the observed failure surface with a safety factor of 1 . The failure conditions attained in the model should produce estimates for parameters such as the friction angle and the cohesion at the time of failure. Once the conditions of the actual failure are determined, the obtained values for the slope geotechnical parameters are relatively realistic.

\subsection{Developing the landslide zonation map}

A landslide zoning map can be constructed to delimit the areas subject to retrogressive landslide hazards. A mapping method has been proposed for eastern Canada by MTMDET (2017) and Turmel et al. (2018); however for other locations, as Norway, various methods can be used, e.g., the 1:15 and the NIFS approaches (Haugen et al., 2017; Karlsrud et al., 1985; NIFS, 2016).

Topography is used to identify all slopes at risk due to their geometry (height $₫ 5 \mathrm{~m}$ and an angle of inclination $\otimes 14^{\circ}$ ). These slopes are then characterized further by their most representative material and the presence or absence of erosion. A realistic assumption is that landslides that have occurred over time in a given area result from specific conditions, and areas sharing similar characteristics should produce landslides having similar retrogression distances. Thus, a statistical analysis of previous landslides in the area can be used to determine the potential distance of retrogression for each slope. This approach can determine constraint areas as potential danger zones at the slope top and the bottom.

\subsection{Conducting a site stability analysis}

Detailed stability analysis can be undertaken for specific needs, i.e., types of infrastructure, on sites located within a constrained area. More advanced numerical modelling of flowslides and spread landslides can also be undertaken.

\section{Study Area}

We selected the Saint-Jean-Vianney (SJV) area in the Saguenay region of Quebec, Canada, to test our methodology. This area is well known for its very thick deposits of sensitive clay and contains the scars of at least two major landslides, which occurred in 1663 and 1971 (Figure 3). The 1663 landslide affected approximately $22 \mathrm{~km}^{2}$ (Lasalle and Chagnon 1968). This event is at the origin of the designation of les terres rompues ("broken lands") for this area along the Saguenay River (Bouchard 1991). The 1971 landslide was much smaller, having a total area of $0.2 \mathrm{~km}^{2}$ (Roy, 2016). Triangular in shape, this slide is located near the center of the 1663 landslide scar (Figure 3). On May 4, 1971, during a particularly rainy spring, part of the village of Saint-Jean-Vianney was swept away by this landslide. A total of 42 houses were destroyed, and 31 people died during the event. 
A geotechnical study carried out following the 1971 event (LaRochelle 1974) characterized the main parameters of the landslide. However, given the specific context of this landslide inside a larger and older slide, it remains difficult to assess the possibility of a similar event reoccurring in the same area (Roy 2016). To commemorate the 1971 tragedy, regional authorities are planning installations for educational, geotourism, and historical purposes in the slide area (Ville de Saguenay 2007). The security of the site and its users requires that a geotechnical study be conducted over the larger area surrounding the scar of the 1971 event.

\section{Results}

\subsection{Developing the 3D model of the SJV area}

\section{a) Creating the database for the SJV area}

A hydrogeological database has been developed for the Saguenay-Lac-Saint-Jean region as part of a groundwater data acquisition program-Programme d'acquisition de connaissance sur les eaux souterraines, CERM-PACES (2013). This regional database includes data from all regional boreholes and wells, other relevant information, and the interpretation of stratigraphic sections (Figure 4). The stratigraphic sections 511 \& 514 from this CERM-PACES database indicate that a clay layer, averaging 30 $\mathrm{m}$ thick, covers the bedrock. An intercalated discontinuous till layer, 1 to $5 \mathrm{~m}$ thick, is also present.

Given that the objective of the PACES project was related to groundwater resources, the thick clay deposits of the SJV area were not fully described in the initial CERM-PACES (2013) project, apart from the abovementioned sections.

For topographic data, we relied on a recent LiDAR (light detection and ranging) survey covering the SJV area. We undertook an initial interpretation of the regional stratigraphy with this LiDAR data. We then selected points for which the stratigraphy was known and added this new data to the database.

\section{b) Acquiring and interpreting the geophysical data across the SJV area}

In 2019, we conducted a field campaign using TEM to improve the data coverage within the study area. We added 75 new data points (blue dots in Figure 5), resulting in 18 pseudo-sections of material electrical resistivity.

Control points represent log data where the stratigraphy is known. During our field work, we conducted TEM surveys near these points. We then compared the electrical resistivity values for each lithology, using the Palacky (1987) chart (Figure 2) as a reference, with the observed stratigraphy at the control points (Table 1). 
Table 1

Comparison of electrical resistivity values of our 2019 TEM surveys with the lithology of the control points within the Saint-Jean-Vianney (SJV) area.

\begin{tabular}{|lllll|}
\hline & Clay & Sand & Gravel & Rock \\
\hline Minimum & 1.51 & 35.37 & 95.61 & 0 \\
\hline Maximum & 72.50 & 254.60 & 402.10 & 0 \\
\hline Mean & 25.97 & 143.85 & 228.29 & 0 \\
\hline Standard deviation & 19.92 & 88.63 & 101.35 & 0 \\
\hline Number of values & 60 & 14 & 18 & 0 \\
\hline Proposed range & $0-50$ & $50-200$ & $200-1000$ & $\geq 1000$ \\
\hline * Value in $\Omega \cdot m$ & & & & \\
\hline ** Comparison carried out on five TEM surveys with control points within $50 \mathrm{~m}$. \\
\hline
\end{tabular}

The observed resistivity values for sand and gravel (Table 1) are much lower than the Palacky (1987) values. These large differences underline the importance of adapting the chart to the specific territory under study. We therefore proposed new ranges of electrical resistivity for each material. It must be noted that fieldwork occurred mostly in the spring when the regional soils are highly saturated.

In the Palacky (1987) chart, the resistivity ranges of the materials sometimes overlap; however, we preferred to differentiate each range of values and avoid any overlap. A given value fits only one material; this approach therefore facilitates interpreting the data in the subsequent steps. The minimum value for a given material was established as the average of the maximum of the lower category and the minimum of the following category. To separate clay from sand, for example, we obtained a value of 50 by rounding roughly the average of the values of 35.37 (minimum value for sand) and 72.5 (maximum value for clay). Because of a lack of values for rock, the Palacky (1987) chart set this range at a value of $\geq 1000$.

Using this new chart and the pseudo-sections, we converted all TEM surveys into stratigraphy logs, and the results were entered into the database.

c) Interpreting the soil stratigraphy within the SJV area

We interpreted the stratigraphy between data points using ArcGIS (ESRI 2015) and the Arc Hydro Groundwater tools (Aquaveo 2019).

We constructed 20 stratigraphic sections (Figure 6) in the study area after accounting for the spatial distribution of the data points. Two sections rely exclusively on borehole logs and serve as references for the other 18 sections based on the TEM pseudo-section data. For each section, topography and the PACES-interpreted surface deposits (Rouleau and Daigneault 2013) are displayed, as well as all streams, 
intersections with other sections, TEM and borehole logs, and other structural elements. We used all this information to interpret each section and ensured that the intersections between sections were concordant.

During this process, we reinterpreted some TEM logs to provide a better fit to the surrounding data. As well, we found large differences in precision between the borehole and the TEM logs. Borehole data scans identify different layers of thickness at a meter-scale resolution and less, whereas TEM readings produce average values that cannot be interpreted at less than a meter scale. Given that the SJV area has been affected by at least two major landslides, these events resulted in many alterations of the thin clay and sand layers across the study area that the TEM surveys could not differentiate; we therefore had to simplify the description of some sections.

A limited number of borehole logs describe the till layer (12 of 218 boreholes), and it is difficult to differentiate till from sand or gravel on the basis of their respective electrical resistivities. Consequently, the till deposit has been integrated into the granular layers. Moreover, the low precision of the TEM survey at less than a meter-scale resolution and the complex stratigraphy of the SJV area restricted our interpretation to four layers. Ordered from the surface downward, the first is a granular alluvial sedimentdominated layer (Granular 2). The second layer is the clay-silt dominant surface layer (Clay), and the third is a granular glaciomarine sediment-dominated layer (Granular 1). The final layer is the bedrock. This simplified stratigraphy is considered sufficient for geotechnical purposes.

d) Creating the 3D model of the SJV area

To export data from ArcGIS to Leapfrog, we used some of the methodology developed by Chesnaux et al. (2011) for building a geodatabase to map the hydrogeological features and produce a 3D modeling of groundwater systems. This approach consists of creating virtual boreholes at $50 \mathrm{~m}$ intervals within the previously developed sections on the basis of the geological interpretation of these sections. The augmented data set was imported into Leapfrog Geo software (Seequent 2020). The resulting 3D model consists of, from the bottom to top, the bedrock, the Granular 1 layer, the clay layer, and then the Granular 2 layer. (Figure 7).

\subsection{Assessing the values of geotechnical parameters across the SJV area}

During fieldwork, we collected clay cores at three locations (labels 1-3 on Figure 8 ). We collected six Shelby tube cores, two at each location. The Shelby tubes were $700 \mathrm{~mm}$ long, having a $75 \mathrm{~mm}$ external 
diameter and $73 \mathrm{~mm}$ internal diameter. We then produced 31 samples, each approximately $10 \mathrm{~cm}$ long, from these Shelby cores. We used nine in the laboratory tests (Table 2), and the 22 samples were sealed in paraffin.

Table 2

Description of the samples collected in the Saint-Jean-Vianney (SJV) area for laboratory tests.

\begin{tabular}{|c|c|c|c|c|c|c|}
\hline Location & Sample & Sediment & Color* & Odor & Observations & $\begin{array}{l}\text { Log data } \\
\text { (Sampling } \\
\text { date; } \\
\text { depth) }\end{array}$ \\
\hline 1 & $\begin{array}{l}\text { TM1- } \\
01\end{array}$ & $\begin{array}{l}\text { Silted } \\
\text { clay }\end{array}$ & $\begin{array}{l}\text { Greenish } \\
\text { gray } \\
(5 Y 4 / 2)\end{array}$ & None & $\begin{array}{l}\text { Presence of silty layers and } \\
\text { an orange layer (rust). A } \\
\text { piece of plastic wrap was } \\
\text { found in the sample. }\end{array}$ & $\begin{array}{l}2019-05- \\
09 \\
0.00-- \\
0.12 \mathrm{~m}\end{array}$ \\
\hline 1 & $\begin{array}{l}\text { TM2- } \\
04\end{array}$ & $\begin{array}{l}\text { Silted } \\
\text { clay }\end{array}$ & $\begin{array}{l}\text { Greenish } \\
\text { gray } \\
(5 Y 3 / 2)\end{array}$ & None & & $\begin{array}{l}2019-05- \\
09 ; 0.35- \\
0.45 \mathrm{~m}\end{array}$ \\
\hline 1 & $\begin{array}{l}\text { TM2- } \\
06\end{array}$ & $\begin{array}{l}\text { Silted } \\
\text { clay }\end{array}$ & $\begin{array}{l}\text { Greenish } \\
\text { gray } \\
(5 Y 4 / 2)\end{array}$ & None & $\begin{array}{l}\text { Presence of a millimetric silt } \\
\text { layer. }\end{array}$ & $\begin{array}{l}2019-05- \\
09 ; 0.55- \\
0.70 \mathrm{~m}\end{array}$ \\
\hline 2 & $\begin{array}{l}\text { TM3- } \\
02\end{array}$ & $\begin{array}{l}\text { Silted } \\
\text { clay }\end{array}$ & $\begin{array}{l}\text { Gray } \\
(2,5 Y \\
3 / 1)\end{array}$ & None & $2 \mathrm{~mm}$ thick silt layer & $\begin{array}{l}2019-10- \\
01 ; 0.10- \\
0.20 \mathrm{~m}\end{array}$ \\
\hline 2 & $\begin{array}{l}\text { TM3- } \\
04\end{array}$ & $\begin{array}{l}\text { Silted } \\
\text { clay }\end{array}$ & $\begin{array}{l}\text { Gray }(5 Y \\
3 / 1)\end{array}$ & $\begin{array}{l}\text { Slight } \\
\text { organic } \\
\text { odor }\end{array}$ & $\begin{array}{l}\text { Centimeter-thick silty } \\
\text { horizon in the center of the } \\
\text { sample. }\end{array}$ & $\begin{array}{l}2019-10- \\
01 ; 0.30- \\
0.42 \mathrm{~m}\end{array}$ \\
\hline 2 & $\begin{array}{l}\text { TM4- } \\
04\end{array}$ & $\begin{array}{l}\text { Silted } \\
\text { clay }\end{array}$ & $\begin{array}{l}\text { Gray }(5 Y \\
3 / 2)\end{array}$ & None & $\begin{array}{l}\text { A silty horizon of } \\
\text { approximately } 1.5 \mathrm{~cm} \text { in the } \\
\text { center of the sample }\end{array}$ & $\begin{array}{l}2019-10- \\
01 ; 0.30- \\
0.42 \mathrm{~m}\end{array}$ \\
\hline 3 & $\begin{array}{l}\text { TM6- } \\
01\end{array}$ & Clay, silt & $\begin{array}{l}\text { Gray } \\
(2,5 Y \\
3 / 1)\end{array}$ & None & $\begin{array}{l}\text { Slightly oxidized on the } \\
\text { surface. }\end{array}$ & $\begin{array}{l}2019-10- \\
01 ; 0.00- \\
0.10 \mathrm{~m}\end{array}$ \\
\hline 3 & $\begin{array}{l}\text { TM6- } \\
03\end{array}$ & Clay, silt & $\begin{array}{l}\text { Gray } \\
(2,5 Y \\
3 / 1)\end{array}$ & None & & $\begin{array}{l}2019-10- \\
01 ; 0.19- \\
0.30 \mathrm{~m}\end{array}$ \\
\hline 3 & $\begin{array}{l}\text { TM6- } \\
04\end{array}$ & Clay, silt & $\begin{array}{l}\text { Gray } \\
(2,5 Y \\
3 / 2)\end{array}$ & None & $\begin{array}{l}\text { A small earthy mass is } \\
\text { present in the sample. }\end{array}$ & $\begin{array}{l}2019-10- \\
01 ; 0.30- \\
0.47 \mathrm{~m}\end{array}$ \\
\hline
\end{tabular}

The nine samples were used for triaxial compression tests according to the ASTM standard (ASTM D2850-15, 2015). The results presented in Table 3 include the maximum principal stress at failure 
$\left(\sigma_{1 \text { failure }}\right)$, the minimum principal stress at failure $\left(\sigma_{3 \text { failure }}\right)$, and the undrained shear strength $\left(\mathrm{c}_{\mathrm{u}}\right)$. These results allow estimates of the cohesion (c) and the friction angle $(\varphi)$ for each sample location (Table 4) (Holtz and Kovacs 1981). We applied the Mohr-Coulomb failure criteria to obtain the values presented in Table 4. These values show that the cohesion and internal friction angle of the soils are consistent for each location; therefore, we can state that the average cohesion (locations 1 and 3 ) of the clay is 55.37 $\mathrm{kPa}$, and the average internal friction angle is $13.99^{\circ}$. Note that the test on sample TM4-04 from Location 2 does not show conclusive results; the sample had already fractured at two places prior to the test, which resulted in lower resistance to axial stress. All other tests are conclusive.

We used six of nine samples to estimate the plastic and the liquid limits according to BNQ-2501-090; BNQ (2019) (Table 5). The results are reliable, and average values have been computed for each location. We also carried out a sedimentation test (BNQ-2501-025; BNQ (2013) on TM2-06 and TM3-02; the results are presented in Table 6. Both samples used for the sedimentation test show near equal quantities of clay and silt (Table 6). The difference between these two samples relates to the presence of different numbers of thin silt beds. In general, the soil in the area can be defined as "CL" according to the Unified Soil Classification System (Holtz and Kovacs 1981), i.e., inorganic clays of low to medium plasticity.

Table 3

Triaxial compression test results for the samples collected from the Saint-Jean-Vianney (SJV) area.

\begin{tabular}{|c|c|c|c|c|}
\hline Area & Sample & $\sigma_{1 \text { failure }}(\mathrm{kPa})$ & $\sigma_{3 \text { failure }}(\mathrm{kPa})$ & $\mathrm{c}_{\mathrm{u}}(\mathrm{kPa})$ \\
\hline \multirow[t]{3}{*}{1} & TM1-01 & 199.48 & 50 & 74.74 \\
\hline & TM2-04 & 289.13 & 100 & 94.57 \\
\hline & TM2-06 & 437.98 & 200 & 118.99 \\
\hline \multirow[t]{3}{*}{2} & TM3-02 & 366.63 & 50 & 158.31 \\
\hline & TM3-04 & 478.20 & 100 & 189.10 \\
\hline & TM4-04 & 398.00 & 200 & 99.00 \\
\hline \multirow[t]{3}{*}{3} & TM6-01 & 222.62 & 50 & 86.31 \\
\hline & TM6-03 & 357.38 & 100 & 128.69 \\
\hline & TM6-04 & 488.73 & 200 & 144.37 \\
\hline Inco & ssive re & & & \\
\hline
\end{tabular}


Table 4

Friction angle and cohesion at each location for the samples collected from the Saint-JeanVianney (SJV) area.

\begin{tabular}{|lll|}
\hline Location & $\boldsymbol{\varphi}\left({ }^{\circ}\right)$ & $\mathbf{c}(\mathrm{kPa})$ \\
\hline $\mathbf{1}$ & 12.81 & 50.70 \\
\hline $\mathbf{2}$ & - & - \\
\hline $\mathbf{3}$ & 15.16 & 60.04 \\
\hline Average & 13.99 & 55.37 \\
\hline
\end{tabular}

Table 5

Liquid limit $\left(\mathrm{W}_{\mathrm{l}}\right)$, plastic limit $\left(\mathrm{W}_{\mathrm{p}}\right)$, and plasticity index $\left(I_{p}\right)$ for six samples collected from the SaintJean-Vianney (SJV) area.

\begin{tabular}{|lllll|}
\hline Location & Sample & WI (\%) & Wp (\%) & Ip (\%) \\
\hline $\mathbf{1}$ & TM1-01 & 44.10 & 25.26 & 18.84 \\
\cline { 2 - 5 } & TM2-04 & 42.79 & 24.87 & 17.93 \\
\cline { 2 - 5 } $\mathbf{2}$ & Average & 43.45 & 25.06 & 18.39 \\
& TM3-04 & 39.36 & 21.96 & 17.40 \\
\hline \multirow{3}{*}{3} & TM4-04 & 40.03 & 21.97 & 18.06 \\
& Average & 39.70 & 21.96 & 17.73 \\
& TM6-03 & 41.36 & 24.87 & 16.49 \\
\cline { 2 - 5 } & TM6-04 & 42.28 & 25.01 & 17.27 \\
\cline { 2 - 5 } & Average & 41.82 & 24.94 & 16.88 \\
\hline
\end{tabular}

Table 6

Sedimentation test results for two samples collected from the Saint-Jean-Vianney (SJV) area.

\begin{tabular}{|lcc|}
\hline & TM2-06 & TM3-02 \\
\hline Clay & $47.4 \%$ & $55.0 \%$ \\
\hline Silt & $52.6 \%$ & $45 \%$ \\
\hline e) Back analysis of a past landslide in the SJV area \\
\hline
\end{tabular}

For the back-analysis phase, we selected a small landslide along the Aux Vases River to determine soil geotechnical parameters at a large scale. This small slip, which occurred between 1971 and 1975, was 
identified by analyzing available aerial photos covering the last 50 years. Only two aerial photos are available for this location during this period, one in 1971 and one in 1975; thus, this landslide occurred after the 1971 SJV event and before the 1975 air photo survey.

Photo A (Figure 9A) shows the slope condition in 2015. Photo B (Figure 9B) shows the pre-landslide slope. The scar of an initial slip is delimited by a yellow line on Photo B. The apex of the initial slip is 40 $\mathrm{m}$ from the river, whereas that of the final slip is $120 \mathrm{~m}$ distant from the river. The elevation at the top and bottom of the slope of the initial slip is approximately $40 \mathrm{~m}$ and $7 \mathrm{~m}$, respectively. The $40 \mathrm{~m}$ estimate is extrapolated from the heights of the northern and southern ends of the present-day landslide scar. The estimated pre-slide slope of the 1971 embankment is $39.5^{\circ}$. The estimated 1971 embankment geometry places the top of the slope at $40 \mathrm{~m}$ from the slope foot and a height of $33 \mathrm{~m}$. The embankment height is then computed to be $49.76 \mathrm{~m}$ for the $120 \mathrm{~m}$ from the foot to the top of the slip (Figure 10).

We introduced the 1971 slope geometry (Figure 10) and the present-day slope profile into the Slide software. An analytical slope stability approach (Richer et al. 2020) can undertake a back analysis (Rocscience 2018). To estimate the shear strength parameter of the soil, we undertook several iterations of slope stability modeling using various input values of soil cohesion and analytical methods. The density $(\mathrm{Y})$ of the clay soil was estimated at $18.6 \mathrm{kN} / \mathrm{m} 3$ from the triaxial tests. To determine the shear strength of the soil, we varied the values of one parameter at a time, either the cohesion value or the friction angle, as back analysis is not possible with two unknown variables. Slope stability is not sensitive to the friction angle of the clay; therefore, the laboratory estimated value $\left(14^{\circ}\right)$ was considered as the known value.

Figure 11 illustrates the model geometry used in the Slide software and presents the nearest approximation of the failure surface for the interpreted topography. We found that the best conceptual analysis method for representing the slip profile is the "Corps of Engineers \#2"(U.S. Corps of Engineers 2003). For all failure geometries that we considered, a cohesion value of $60 \mathrm{kPa}$ is required to reach a safety factor of 1 , a cohesion value that lies within the range of values obtained using the triaxial tests (Table 5). Figure 12 shows that the slip profile having the minimum safety factor ( $S F=1$ ) is deeper than that interpreted according to the profile of the observed present slope (purple line). The resulting shape of the slip profile is very similar to the present-day slope profile. Therefore, a cohesion of $60 \mathrm{kPa}$ and a friction angle of $14^{\circ}$ using the "Corps of Engineers \#2" conceptual analysis produced the best profile of the slip.

\subsection{Developing a landslide zonation map for the SJV area}

The Quebec Ministry of Transport has mapped most of Quebec's territory to identify areas at risk of landslides. These zones are delimited by taking into account the characteristics of the soil and conditions related to the land, such as the soil type, the embankment slope, and the history of landslides in the zone. The Saint-Jean-Vianney area is unfortunately not mapped. 
The City of Saguenay has, however, produced its own stress maps to identify zones having embankments with a landslide risk (Figure 12). For these maps, embankment size was determined using the criteria of a height $\geq 5 \mathrm{~m}$ and a slope $\geq 14^{\circ}$ (Ville de Saguenay 2007).

Using the historical aerial photos and the existing LiDAR topography, we undertook an analysis of landslides that have occurred along the Aux Vases and the Petit-Bras rivers (\#1 and \#2 in Figure 12). From this analysis, we could parameterize these landslides and, in particular, estimate retrogression distance. We studied 30 landslides, including the 1971 SJV landslide and the smaller slip used in the back analysis. We applied a third-order moving average (Turmel et al. 2018) to determine the average retrogression distance along both the eastern and western banks of the rivers. Thus, the resulting estimate varies with location along the river. The landslides along the western bank showed greater retrogression than those found along the eastern bank (Figure 13). Note that the 1971 landslide occurred on the western bank.

From this graph, we can map zones having a landslide risk, which takes into account the variable-width areas related to the retrogression distances of past landslides (see Figure 14). The results of this method are more realistic, as they take into account the actual characteristics of the geotechnical and hydrological environments. To design this map, we considered all $\geq 14^{\circ}$ slopes having a height of $\geq 4 \mathrm{~m}$, following the MTMDET (2017). The widths of the areas classified as at risk of landslide were variable; we observed a constraint zone of approximately $80 \mathrm{~m}$ wide for the western bank and about $40 \mathrm{~m}$ wide for the eastern bank (Figure 14).

\subsection{Local slope stability analysis of the SJV area}

The database, the 3D model, and the zonation map created for the SJV area facilitate further stability analysis of slopes across the area. A stratigraphic section can be created for a local study site. A back analysis can then be conducted at an existing landslide site to estimate the soil geotechnical parameters at a true scale and identify the appropriate analytical method to use for calculating slope stability. Finally, the mapping of the constraint zone will identify the main zones at risk of landslide, and any project proposed for the SJV area must first take into account this map of landslide risk (Figure 14). The site of planned infrastructure located in a constraint area should be investigated further through a local stability analysis. The database could then be used to generate a 3D model of the site, and this model could then be imported into modeling software to assess slope stability. The data acquired from the back analysis of past landslides helps assign realistic values to the geotechnical parameters used in the stability analysis.

As an example, we conducted a local stability analysis of the slope near the site of the planned lookout (Figure 15). Its projected location is at the top of an embankment characterized by a landslide risk. We obtained the topography of the section from a 3D model of the site that also indicates that the slope is composed entirely of clay. 
Our modeling of the lookout slope, using the Slide software, assumed a uniform load weight, and we applied the "Corps of Engineers \#2" method, as it was the most appropriate for this analysis on the basis of the earlier back analysis. The geotechnical soil property values were also determined through the back analysis: a fully saturated clay soil, $Y=18.6 \mathrm{kN} / \mathrm{m}^{3}, \varphi=14^{\circ}$, and cohesion $=60 \mathrm{kPa}$. The uniform weight of the lookout was estimated at $34.01 \mathrm{kPa}$. The modeling (Figure 15) produced a minimum safety factor of 2.764 , which is greater than 1.5 , a conservative value used for a construction at the top of a slope. Thus, the proposed lookout design is safe for this embankment.

\section{Discussion}

LiDAR data have been very useful for mapping the topography, increasing the density of the data points collected from a study area, and enhancing the precision of 3D modeling. Slope geometry is a crucial aspect of stability analysis, as it is a controlling factor of a possible slide, and the precision of LiDARderived data facilitates the detailing of slope geometry.

Adapting the electrical resistivity reference ranges to the study area was more difficult than expected. This difficulty can be partially explained by the complex structure of the Saint-Jean-Vianney soils. The clay is stratified and has been affected by at least two landslides; one partially remolded the soil and created inclined blocks, and the other landslide locally reshaped almost the entire soil mass. Our limited time for fieldwork also complicated the task of adapting the electrical resistivity reference ranges. Ideally, we would have included a greater number of control points. The TEM approach allowed us to obtain data at a sufficient depth; however, the spatial precision of the results was limited at less than a meter-scale resolution. For a specific point on the landscape, TEM results are certainly less accurate than possible borehole data. Nevertheless, TEM is highly useful for interpreting the stratigraphy between boreholes.

The 3D model, as a tool for geotechnical investigation, must fulfill three important tasks for stability analysis: 1) accurately reproduce slope geometry; 2) estimate the depth of the bedrock; and 3) differentiate the major soil deposits, namely clay, sand (granular), and bedrock. The 3D model can be improved by using more exact parameter estimates. We simplified our categorization of the regional sedimentary layers to match the degree of precision of the TEM results. The topography of the rock underlying the study area, however, must be reassessed. The absence of rock data among the control points and the electrical resistivity values of the other interpreted sedimentary materials-moving downward through the accumulated material-suggest that the electrical resistivity values for the rock have been overestimated. The scattered occurrence of rock "peaks" reaching toward the surface, as observed in Figure 7D, reveals that the spacing between the TEM survey points was too great in some areas to reveal continuity between those "peaks".

When identifying the geotechnical parameters of the soil, the presence of multiple silt layers within the clay samples created difficulties in ensuring sufficient samples for the laboratory tests. The triaxial 
laboratory test requiring homogeneous samples, the presence of silt layers distort the results. For two of the three sample locations, our sampling produced conclusive results. We estimated a cohesion of 55,37 $\mathrm{kPa}$ and a friction angle of $14^{\circ}$ for the surface clays of the SJV area. We applied these values to the modeling of a past landslide along the Aux Vases River with the objective of obtaining true-scale values of the geotechnical parameters for this landslide by recreating the failure conditions through the use of the Slide software.

The computed failure surface did not superimpose perfectly on the actual interpreted surface. Nevertheless, the shapes of both surfaces were quite similar and were in close proximity to each other. This difference in the calculated locations of the failure surface-our estimated parameter values at failure were a cohesion of $60 \mathrm{kPa}$ and a friction angle of $14^{\circ}$-likely relates to the accuracy of the prefailure slope geometry. This geometry had to be assessed using topographic estimates derived from aerial photos collected between 1971 and 2015. We also identified that the "Corps of Engineer \#2" stability analysis method provided appropriate results and can be used for further stability assessments for the region. We used an analytical approach because the estimated parameters are quick to compute, and this approach can produce sufficiently reliable results. More accurate results can be obtained using numerical software, which can model the progressive failure mechanism and are better suited for retrogressive landslides in sensitive clays.

Our mapping of the constraint zones followed largely the procedure used by the Saguenay city. We identified all slopes $\geq 14^{\circ}$ having height of $\geq 5 \mathrm{~m}$. Using the 3D model, we determined the main material composing each slope; this was clay in most cases. Along the Aux Vases River, we determined the constraint zones through the statistical analysis of previous slides. For other locations where there was no major vector of erosion, such as a river, we applied a $30 \mathrm{~m}$ wide constraint zone. The produced zonation map can determine whether a planned project lies within a constraint area and whether the development proposal requires further investigation.

\section{Conclusion}

We presented a methodology for developing a landslide hazard assessment across a territory. For this approach, we proposed three tools: 1) a 3D model produced using a geophysical (TEM) survey and an adapted electrical resistivity chart; 2 ) the estimation of true-scale geotechnical parameters using a back analysis of past landslides in the area; and 3) a zonation map of slopes at risk of landslide, which includes constraint areas at the foot and top of these slopes.

The construction of an appropriate 3D model demonstrated that our methodology is effective. We acquired approximately 75 new stratigraphic logs within a 12-day period, without using a drilling campaign. Results could have been improved even further if we had obtained a greater number of control points and more data related to bedrock depth, allowing further adaptation of the electrical resistivity chart. Overall, the developed 3D model demonstrated its utility as a tool for stability analysis. 
Back analysis provided estimates of the geotechnical parameters at the slope scale. A cohesion value of $60 \mathrm{kPa}$ and a friction angle of $14^{\circ}$ produced conclusive results with the stability modeling of a slope affected by a previous landslide. We found the U.S. "Corps of Engineers \#2" analytical method to be the most reliable approach for our study area. Nonetheless, a numerical modeling method that considers the progressive failure mechanism would provide a more exact output and would offer a more reliable approach for slope stability analysis in sensitive clays.

The zonation map constitutes an initial investigation tool for development projects within the study area. The 3D stratigraphy model, which served as the basis of the zonation map, can be combined with the parameter values obtained through other methods described in this paper to undertake stability analysis on other slopes within the study area.

\section{Declarations}

\section{Acknowledgments}

The authors would like to thank the members of the CERM-PACES project at UQAC for their cooperation in conducting the field tests and providing access to various datasets.

\section{Authors' contributions}

Funding acquisition, A.S., M.B.; Methodology, B.R. and A.S.; Project administration, A.S.; Software, B.S.; Supervision, A.S., A.R. and M.B.; Writing - original draft, B.R.; Review \& editing, A.S., A.R. and M.B.

\section{Funding}

The authors would like to thank Promotion Saguenay, the City of Saguenay, the Fondation de l'Universite du Québec à Chicoutimi (FUQAC), and the Mitacs Accelerate program (\#IT11773) for the funding of this research.

\section{Availability of data and materials}

All the datasets that have been used and analysed during the current study is available from the corresponding author on reasonable request.

\section{Competing interests}

I have declare that there is no any competing interests.

\section{References}

1. Aquaveo (2019) "Arc Hydro Groundwater 3.5." https://www.aquaveo.com/software/ahgw-archydrogroundwater-introduction 
2. ASTM D2850-15, Standard Test Method for Unconsolidated-Undrained Triaxial Compression Test on Cohesive Soils, ASTM International, West Conshohocken.

https://standards.globalspec.com/std/9978669/ASTM D2850

3. Bouchard R (1991) Villages Fantômes, Localités Disparues Ou Méconnues Du Haut-Saguenay. Société historique du Saguenay

4. Bureau de normalisation du Québec (BNQ) (2013) "Sols - Analyse Granulométrique Des Sols Inorganiques: BNQ 2501-025 / 2013." https://www.bnq.qc.ca/fr/normalisation/genie-civil-etinfrastructures-urbaines/sols/sols-analyse-granulometrique-des-sols-inorganiques.html

5. CERM-PACES. "Résultats Du Programme d'acquisition de Connaissances Sur Les Eaux Souterraines Du Saguenay-Lac-Saint-Jean." Centre d'études Sur Les Ressources Minérales, Université Du Québec à Chicoutimi.

6. Chagnon JY (1968) Les Coulées d'argile Dans La Province de Québec. Naturaliste Can 95:13271343

7. Chesnaux R, Lambert M, Walter J, Fillastre U, Hay M, Rouleau A, Daigneault R, Annie Moisan, and Denis Germaneau (2011) Building a Geodatabase for Mapping Hydrogeological Features and 3D Modeling of Groundwater Systems: Application to the Saguenay-Lac-St.-Jean Region, Canada. Comput Geosci 37(11):1870-1882. https://doi.org/10.1016/j.cageo.2011.04.013

8. Demers D, Robitaille D, Locat P (2014) and Janelle Potvin. "Inventory of Large Landslides in Sensitive Clay in the Province of Québec, Canada: Preliminary Analysis." In Landslides in Sensitive Clays: From Geosciences to Risk Management, 77-89

9. Dyke AS, Prest VK (1987) Late Wisconsinan and Holocene History of the Laurentide Ice Sheet. Geographie Physique et Quaternaire 41(2):237-263. https://doi.org/10.7202/032681ar

10. ESRI (2015) "ArcGIS Desktop." https://www.esri.com/en-us/arcgis/products/arcgispro/overview\#visualization

11. Fargier $Y$, Fauchard $C$, Meriaux $P$, Royet $P$, Palma-Lopes $S$, Francois D, Cote $P$ (2012) and Frederic Bretar. "Methodology Applied to the Diagnosis and Monitoring of Dikes and Dams." Novel Approaches and Their Applications in Risk Assessment, no. May 2014. https://doi.org/10.5772/16318

12. Geertsema M, Jean-Sébastien L'Heureux (2014) "Controls on the Dimensions of Landslides in Sensitive Clays". Landslides in Sensitive Clays: From Geosciences to Risk Management. Springer Netherlands, Dordrecht, pp 105-117. https://doi.org/10.1007/978-94-007-7079-9_9.

13. Haugen ED, Tveit M, Håkon, Heyerdahl (2017) Mapping Quick Clay Hazard Zones: Comparison of Methods for the Estimation of the Retrogression Distance. Advances in Natural and Technological Hazards Research 46:311-321. Springer Netherlands https://doi.org/10.1007/978-3-319-56487-6_28

14. Holtz RD, Kovacs WD (1981) An Introduction to Geotechnical Engineering. Prentice-Hall Inc, Englewood Cliffs, New Jersey, USA

15. Hungr O, Leroueil S, and Luciano Picarelli (2014) The Varnes Classification of Landslide Types, an Update. Landslides 11(2):167-194. https://doi.org/10.1007/s10346-013-0436-y 
16. Karlsrud K, Aas G, Gregersen O (1985) Can We Predict Landslide Hazards in Soft Sensitive Clay? Summary of Norwegian Practice and Experiences. Publikasjon - Norges Geotekniske Institutt 158:405-429. https://doi.org/10.1016/0148-9062(86)91270-2

17. L'Heureux J-S, Locat A, Leroueil S, Demers D (2014) and Jacques Locat. "Landslides in Sensitive Clays - From Geosciences to Risk Management." In Landslides in Sensitive Clays - From Geosciences to Risk Management, 1-12. https://doi.org/10.1007/978-94-007-7079-9_1

18. LaRochelle P (1974) Rapport de Synthèse Des Études de La Coulée d'argile de Saint-Jean-Vianney. Ministère des richesses naturelles du Québec, " Québec

19. Lasalle P, and Jean-Yves Chagnon (1968) An Ancient Landslide along the Saguenay River, Quebec. Can J Earth Sci 5(3):548-549. https://doi.org/10.1139/e68-049

20. Marko K, Tiit H, Peeter T, and Kalm Volli (2010) Analysis of a Retrogressive Landslide in Glaciolacustrine Varved Clay. Eng Geol 116(1-2):109-116. https://doi.org/10.1016/j.enggeo.2010.07.012

21. Ministère des transports, mobilité durable et électrification des transports du Québec (2017) "Guide d'utilisation Des Cartes de Contraintes Relative Aux Glisement de Terrain Dans Les Dépôts Meubles."

22. Mitchell RJ, Klugman MA (1979) Mass Instabilities in Sensitive Canadian Soils. Eng Geol 14:109134

23. Munsell H (2009) Albert. Munsell Rock-Color Book. Revised

24. Mussett AE, Alan E, Aftab M, Khan (2000) Looking into the Earth: An Introduction to Geological Geophysics. Cambridge University Press

25. Natural hazards-infrastructure for floods and slides (2016)“Metode for Vurdering Av Løsne - Og Utløpsområder for Områdeskred." NVE

26. Palacky GJ (1988) "Resistivity Characteristics of Geologic Targets." In Electromagnetic Methods in Applied Geophysics, 53-129

27. Palacky GJ (1987) Clay Mapping Using Electromagnetic Methods. First Break 5(1198). https://doi.org/10.3997/1365-2397.1987015

28. Richer B, Saeidi A, Boivin M, and Alain Rouleau (2020) Overview of Retrogressive Landslide Risk Analysis in Sensitive Clay Slope. Geosciences 10(8):279.

https://doi.org/10.3390/geosciences 10080279

29. Rocscience (2018) “Slide2:Most Comprehensive 2D Slope Stability Software." 2018. https://www.rocscience.com/software/slide2

30. Rouleau A, Réal, Daigneault (2013)“Dépôts de Surface.” CERM UQAC

31. Roy DW (2016) "Les Glissements de Terrain à Saint-Jean-Vianney, 45 Ans plus Tard. Éléments de Réflexion." Centre d'études Sur Les Ressources Minérales (CERM) de l'Université Du Québec à Chicoutimi (UQAC), no. Cahier 2016-01: 15p. https://constellation.uqac.ca/3713/1/160504SJVianney-Rv2017.pdf 
32. Saeidi A, Maazallahi V, Rouleau A (2016) Back Analysis. Int J Rock Mech Min Sci 88(October):29-33. https://doi.org/10.1016/j.ijrmms.2016.07.008. "Assessment of Slide Surface and Pre-Slide Topography Using Site Investigation Data in

33. Seequent (2020) "Leapfrog Geo." Https://Www.Seequent.Com/Products-Solutions/Leapfrog-Geo/. http://www.leapfrog3d.com/

34. Turmel D, Potvin J, Demers D, Locat P, Locat J Serge Leroueil, Département De, and Université Laval. 2018. "Empirical Estimation of the Retrogression and the Runout Distance of Sensitive Clay Flowslides." Geohazard7,8

35. U.S Corps of Engineers (2003) "Slope Stability." http://www.usace.army.mil/inet/usace-docs/

36. Varnes DJ (1978) Slope Movement Types and Processes. Special Report - National Research Council Transportation Research Board 176:11-33. http://onlinepubs.trb.org/Onlinepubs/sr/sr176/176002.pdf

37. Ville deS (2007) "Carte de Zones de Contraintes Relatives Aux Glissements de Terrain. 1: 5000. 22D06-050-0805."

\section{Figures}




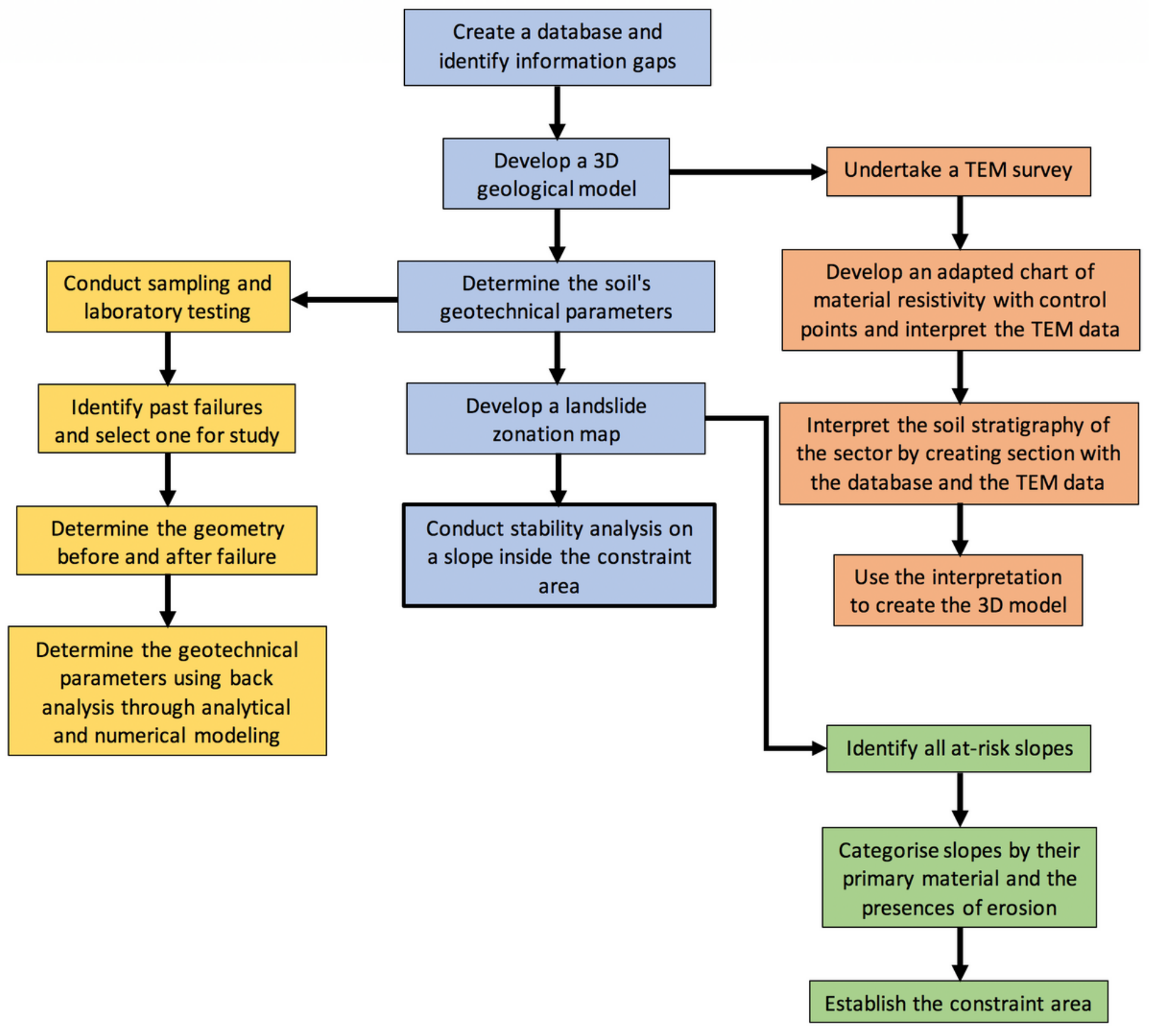

\section{Figure 1}

Evaluation of landslide risk at a regional scale. 


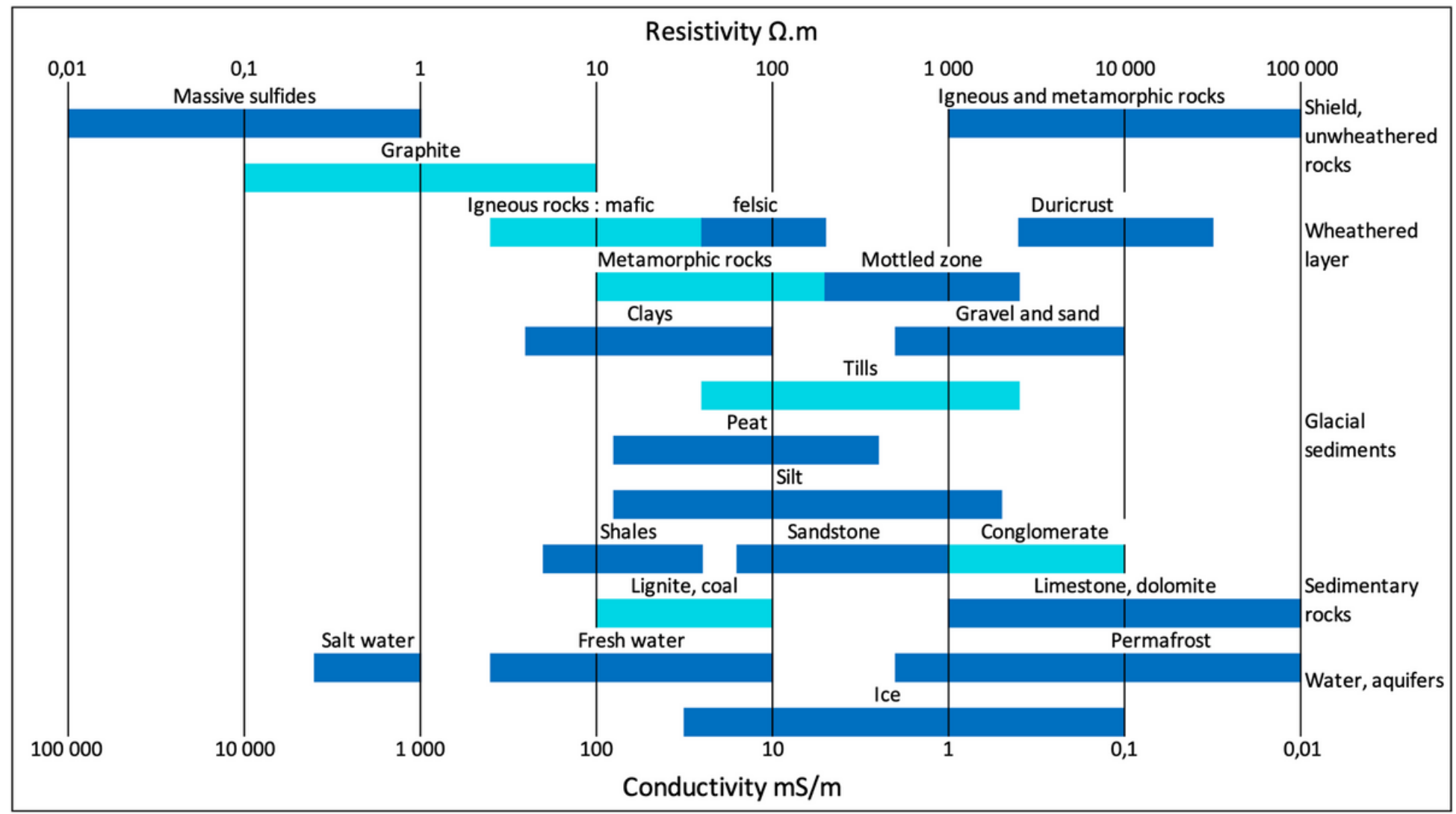

Figure 2

Resistivity (and its inverse, conductivity) of the main earth materials, modified from Palacky (1988) and Fargier et al. (2012).

\section{Figure 3}

Scars of the 1663 and 1971 landslides in the Saint-Jean-Vianney area (modified from Chagnon (1968) and Roy (2016))

\section{Figure 4}

Map of the Saint-Jean-Vianney area showing the known data points and stratigraphic sections from CERM-PACES (2013). The boundaries of the SJV area are delimited by the City of Saguenay, Quebec.

\section{Figure 5}

The 2019 TEM surveys undertaken in the Saint-Jean-Vianney (SJV) area, Quebec. 
Sections created from the TEM surveys and the PACES data points in the Saint-Jean-Vianney (SJV) area, Quebec.

\section{Figure 7}

The 3D model of the sedimentary deposits of the Saint-Jean-Vianney (SJV) area. A) The model with all deposits displayed; B) the model without the Granular 2 unit; C) the model without the Granular 2 and Clay units; and $\mathrm{D}$ ) the bedrock with all overlying deposits removed.

\section{Figure 8}

Location of the collected samples in the Saint-Jean-Vianney (SJV) area, Quebec.

2

Figure 9

Aerial photographs used for the analysis of the small slip. Aerial photos captured in (A) 2015 and (B) 1971. The location of the slip corresponds to location 2 in Figure 8. 


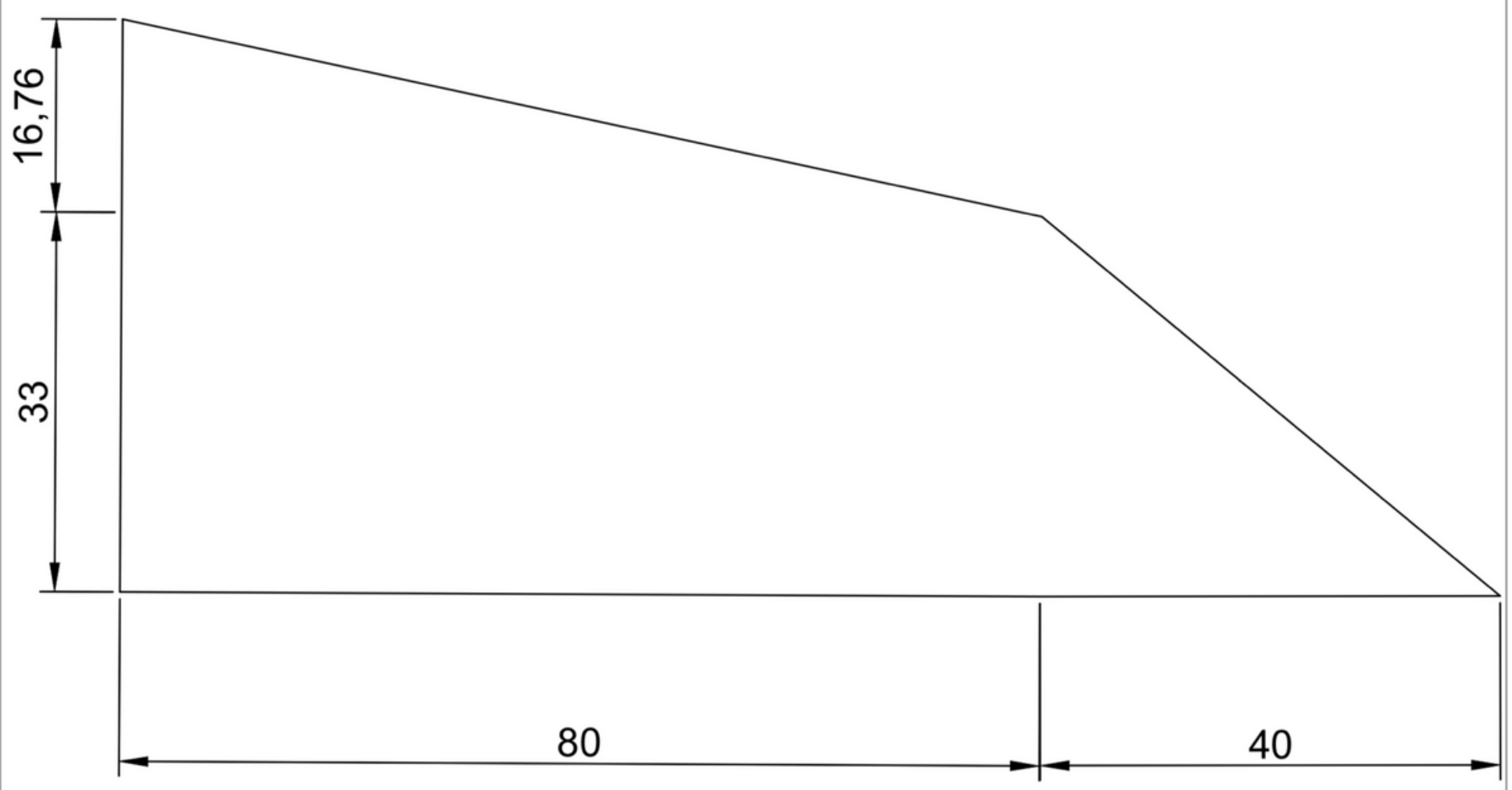

Figure 10

The modeled geometry of the slope in 1971 (in meters) before the small landslide. 


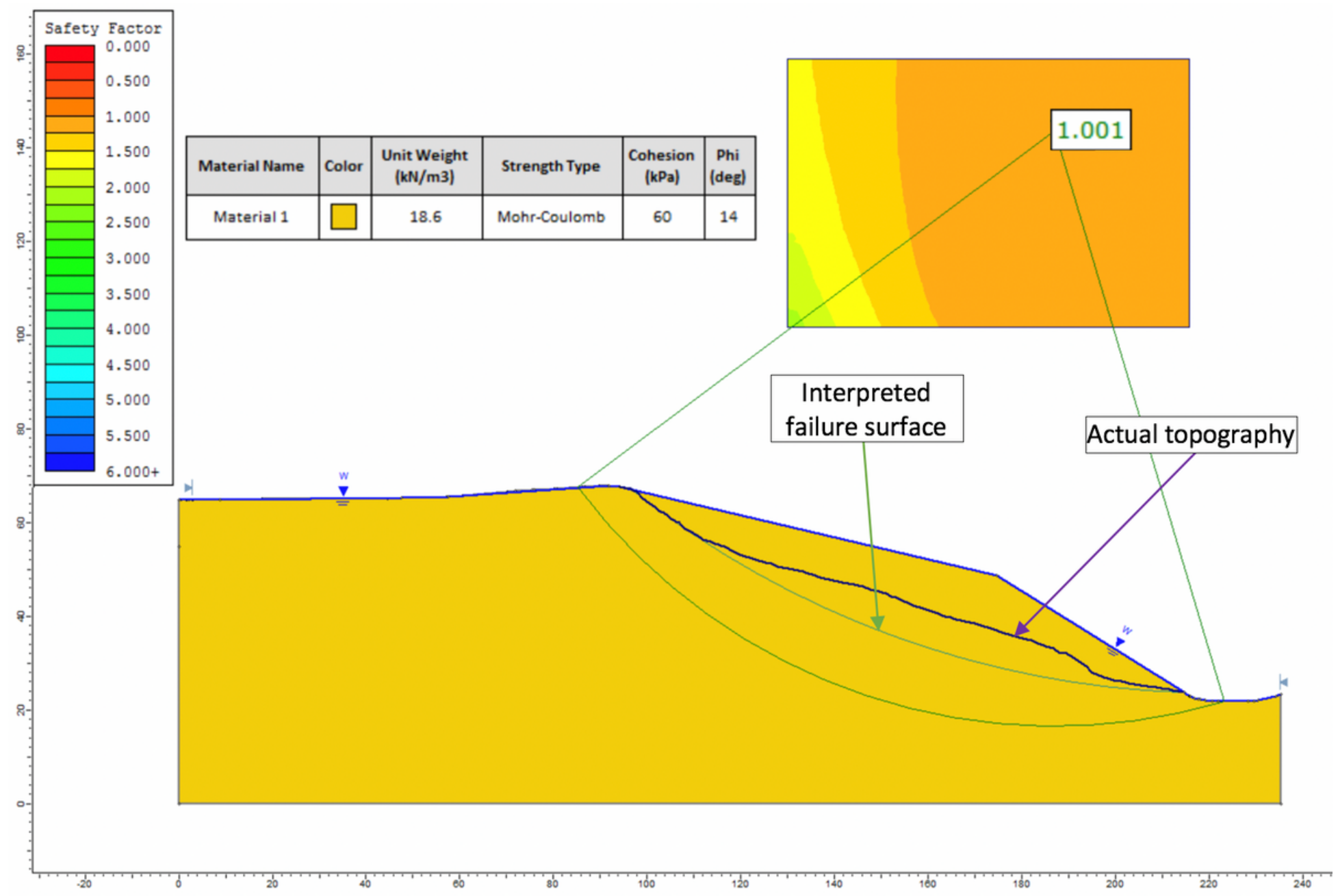

\section{Figure 11}

Back analysis of the small landslide showing the nearest approximation of the interpreted topography using the U.S. "Corps of Engineers \#2" (2003) method best represented the profile of the slip with a cohesion value of $60 \mathrm{kPa}$ and a friction angle of $14^{\circ}$.

\section{Figure 12}

Map of stress zones related to landslides 22D06-050-0805 and 22D06-050-0705, 1:5000 (Ville de Saguenay 2007). 1, Aux Vases River; 2, Petit-Bras River; orange: embankments having a height $\geq 5 \mathrm{~m}$ and a slope of $\geq 14^{\circ}$, composed of soils of an undetermined nature with or without erosion, likely to be affected by landslides of natural or anthropogenic origin; pale yellow: $60 \mathrm{~m}$ protection zone at the top and foot of the slope. 


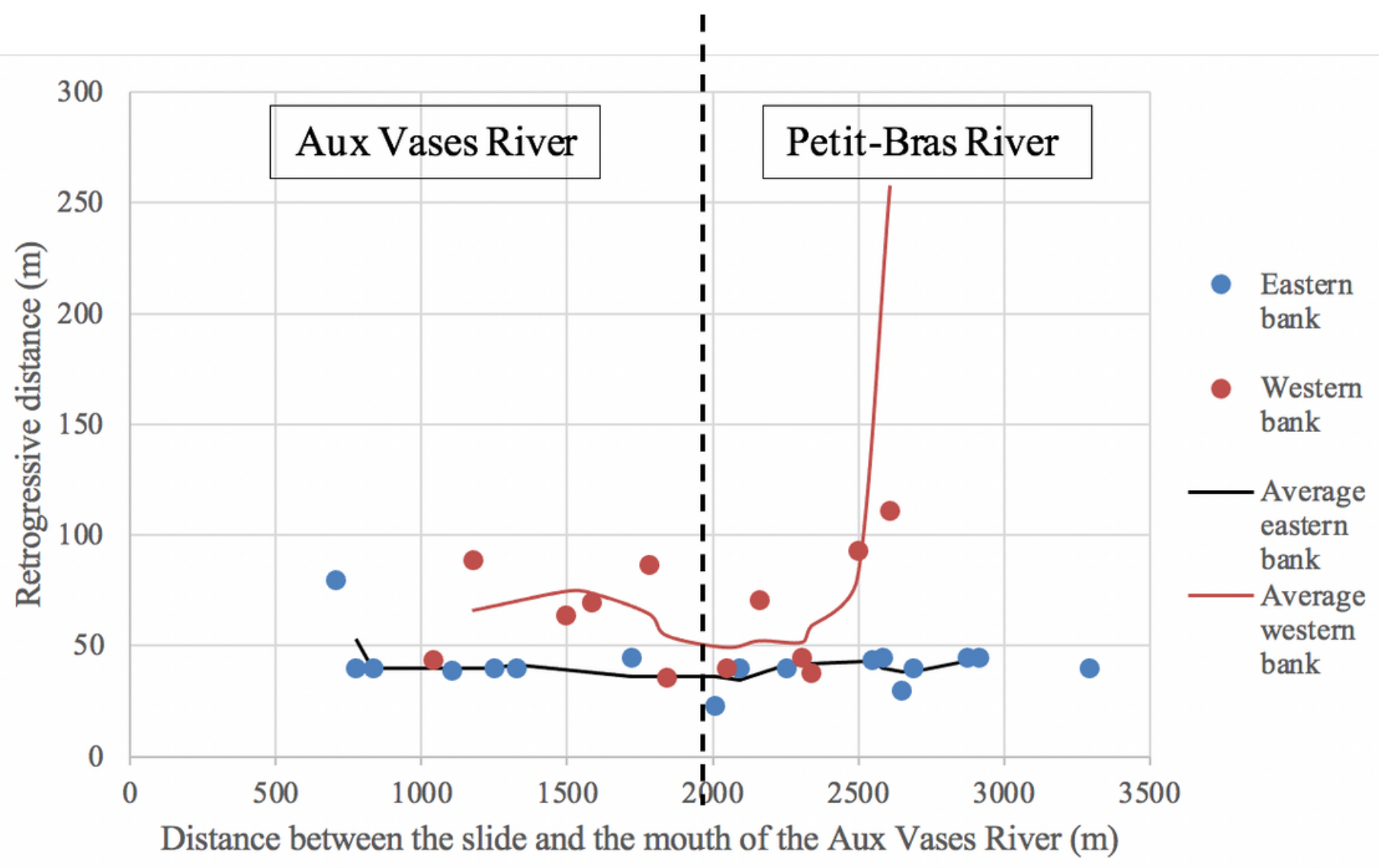

Figure 13

Retrogression distance of the landslides according to their position along the Aux Vases and Petit-Bras rivers.

Figure 14

Map of landslide risk zones for a part of the Saint-Jean-Vianney area. 


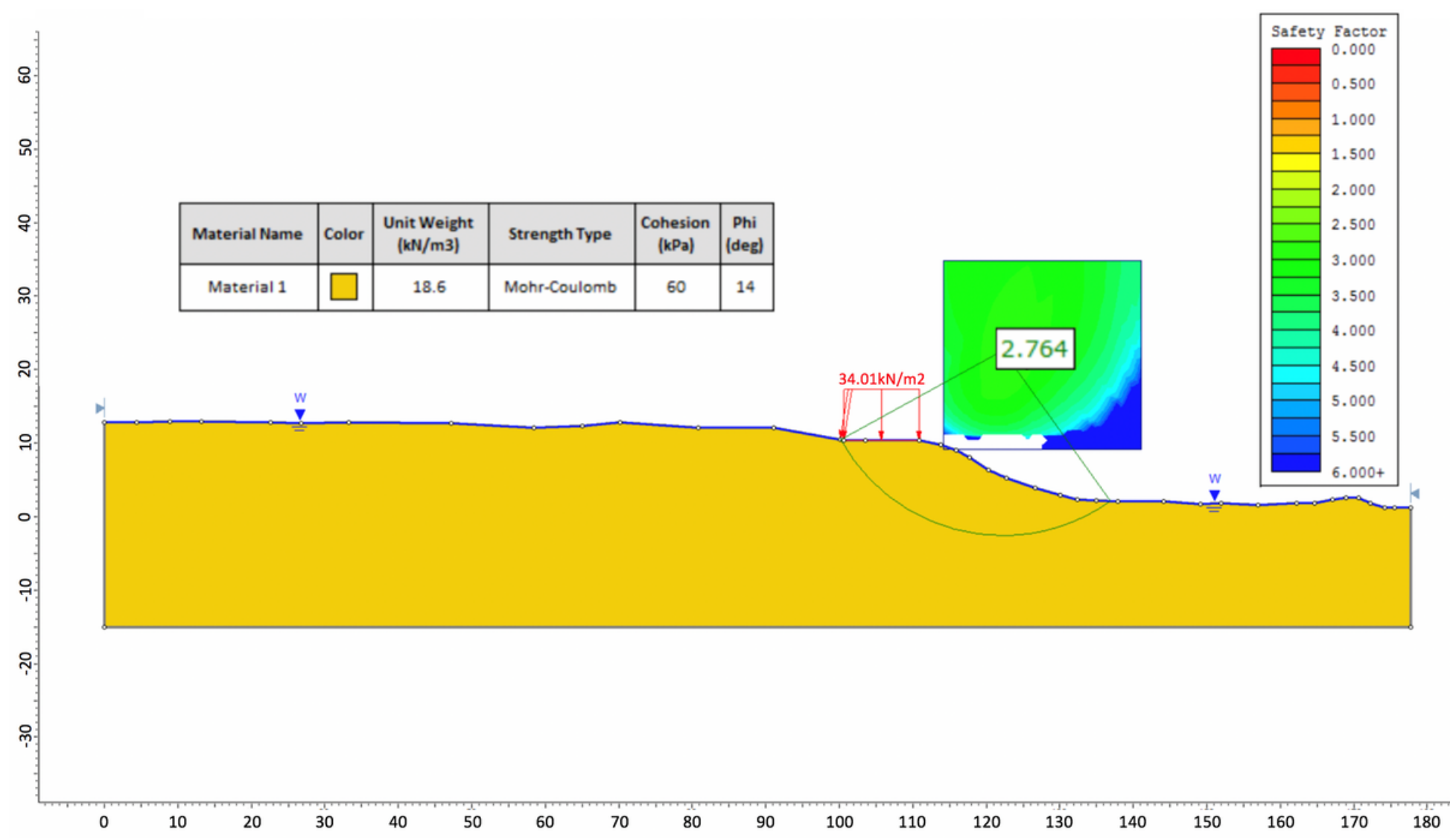

Figure 15

Modeling of the slope of the planned lookout for the Saint-Jean-Vianney site, assuming a uniform weight of any structure (view to the north). 